\title{
PENGARUH AKUPRESURE UNTUK MENGURANGI MUAL MUNTAH POST OPERASI: LITERATURE REVEW
}

\author{
The Influence of Acupressure to Reduce Post Operative Nausea and Vomiting : Literature \\ Revew
}

\author{
Baiq Emy Nurmalisa, Jurana, Nasrul \\ Poltekkes Kemenkes Palu \\ (nurmalisa@gmail.com)
}

\begin{abstract}
ABSTRAK
Mual muntah post operasi merupakan komplikasi yang umum terjadi setelah pasien menjalani operasi baik dengan general, regional maupun lokal anastesi. Penggunaan obat-obatan antiemetik terbukti efektif mengurangi mual muntah akan tetapi beberapa dari jenisnya menimbulkan efek samping. Akupresure dijadikan sebagai alternative pilihan untuk mengurangi insiden mual muntah post operasi. Tujuan penelitian ini adalah untuk mengetahui keefektifan dan kemananan akupresure P6 untuk mencegah mual muntah post operasi. Elektronik database yang digunakan dalam mencari literature adalah (PubMed), google scholar, NEJM, Proquest mulai tahun 2006-2016. Intervensi yang digunakan adalah akupresure P6. Adapun outcome utama dari penelitian adalah pencegahan mual muntah post operasi. Dari 8 hasil literature yang melibatkan 1638 responeden menunjukkan bahwa akupresure dapat mengurangi mual muntah post operasi dalam waktu dan durasi yang bervariasi.
\end{abstract}

\section{Kata kunci : Akupressure; Mual; Muntah; Post Operasi}

\section{ABSTRACT}

Postoperative nausea and vomiting is a common complication that occurs after the patient undergoes surgery either with general, regional or local anesthesia. The use of antiemetic drugs has been shown to be effective in reducing nausea and vomiting, but some of them cause side effects. Acupressure is used as an alternative option to reduce the incidence of postoperative nausea and vomiting. The purpose of this study was to determine the effectiveness and safety of acupressure P6 to prevent postoperative nausea and vomiting. Electronic databases used in searching for literature are (PubMed), google scholar, NEJM, Proquest from 2006-2016. The intervention used was acupressure P6. The main outcome of the study was prevention of postoperative nausea and vomiting. From 8 literature results involving 1638 respondents showed that acupressure can reduce postoperative nausea and vomiting in various time and duration.

Keywords : Acupressure; Nausea; Vomiting; Post Operation

https://doi.org/10.33860/jik.v14i2.275

(C) 2020 by the authors. Submitted for possible open access publication under the terms and conditions of the Creative Commons Attribution (CC BY SA) license (https://creativecommons.org/licenses/by-sa/4.0/).

\section{PENDAHULUAN}

Mual muntah post operasi merupakan salah satu keluhan yang paling sering dialami oleh pasien yang menjalani operasi dengan anastesi general, regional, ataupun lokal anastesi, ${ }^{1}$ dengan insidensi mencapai $80 \%{ }^{2}$ Terapi obat-obatan dapat memberikan keefektifan dalam mencegah atau mengobati mual muntah post operasi. Meskipun demikian, mual muntah post operasi merupakan permasalahan yang masih terjadi meskipun sudah ada penggunaan antiemetik. ${ }^{3}$ 
Adanya mual muntah yang terjadi pada pasien menyebabkan terjadinya keterlambatan recovery pasien dari efek anastesi, memperpanjang length of stay, dan meningkatkan biaya perawatan. ${ }^{3}$ Selain itu, pada pasien-pasien -pasien yang menjalani kraniotomi, muntah sering terjadi dan dapat menyebabkan penekanan cerebral intravaskular atau penekanan intrakranial yang dapat menyebabkan komplikasi atau permasalahan yang berat. Penelitian menunjukkan bahwa rata-rata insiden mual muntah setelah operasi mencapai $38.3 \%$ untuk operasi umum, dan meningkat insidensinya pada pasien yang menjalani operasi kraniotomi sebesar $50-79 \%$. 4,5

Tenaga medis terus mencari pendekatan yang lebih murah, meningkatkan pasien outcome, sederhana, dan dengan metode non invasive untuk mencegah mual muntah. Beberapa waktu terakhir, pendekatan non farmakologi mulai dijadikan sebagai terapi komplementer untuk mencegah mual muntah. Adapun beberapa teknik yang digunakan yaitu acupuncture, electro-acupuncture, laser acupuncture, acupoint stimulation, acupressure, dan capsicum plaster. Pericardium (P6) point dapat mengurangi mual muntah dimana titik P6 ini terletak antara tendon palmaris longus dan otot fleksor carpi radialis, $4 \mathrm{~cm}$ proksimal pergelangan tangan. ${ }^{6}$ Mekanisme titik P6 untuk mengurangi mual muntah masih belum jelas. Beberapa penelitian yang menunjukkan stimulasi P6 dapat mengurangi mual muntah secara signifikan akan tetapi di lain sisi ada yang menyebutkan tidak signifikan.

Adapun tujuan penulis melakukan penulisan sistematik review ini adalah untuk mengkaji atau menginvestigasi pengaruh akupresure stimulasi titik P6 untuk mengurangi insiden mual muntah post operasi.

\section{METODE PENELITIAN}

Keseluruhan prosedur dalam melakukan sistematik review ini adalah merujuk penulisan guidilines Preferred Reporting Items for Systematic Reviews and Meta-Analyses (PRISMA). Elektronik database yang digunakan dalam mencari literature adalah (PubMed), google scholar, NEJM, Proquest mulai tahun 2006-2016. Adapun kata kunci yang digunakan untuk mencari sumber penelitian randomized control trials adalah: 'postoperative complications', 'nausea and vomiting', 'acupuncture', 'acupuncture therapy', 'acupuncture points', 'acupressure', . Penelitian yang dipilih dengan kriteria penelitian randomized controlled trials (RCTs),dan quasy experimental yang meneliti tentang efektifitas dari akupresure titik P6 untuk mengurangi mual muntah post operasi. Penelitian RCT yang membandingkan antara akupresure titik P6 dibandingkan dengan sham treatment atau obat antiemetik. Penggunaan titik P6 bisa menggunakan akupresure wristband, maupun akupresure wristband tetapi yang tidak diletakkan di titik P6. Penelitian yang sudah dipublish dalam bentuk full artikel, menampilkan jumlah intervensi dan kontrol dimasukkan dalam analisis. Seluruh pasien yang menjalani operasi tanpa batasan jenis operasi dan umur. Teknik stimulasi titik P6 dengan menggunakan acupuncture, electro-acupuncture, laser acupuncture, transcutaneous electrical stimulation, acustimulation device, acupressure, dan capsicum plaster; versus sham treatment atau terapi obat-obatan untuk mencegah mual muntah post operasi. Tidak ada batasan durasi pemberian stimulasi akupresure P6 dan waktu pemberian. Durasi pengukuran tidak dibatasi, beberapa penelitain mengukur insiden mual muntah 0-6 jam, 6-24 jam, 0-24 jam dan sebagainya.

\section{HASIL}

Dari hasil review beberapa literature didapatkan 8 literature yang sesuai dengan kriteria dimana melibatkan 1638 responden. Literature mengenai akupresure tersebut diaplikasikan pada pasien dengan berbagai macam jenis post operasi mulai dari post operasi craniotomi, sectio secsaria, tiroid, apendiktomi, gynecological laparoscopic surgery, dan cardiac surgery. Hasil review kedelapan jurnal tersebut menunjukkan bahwa pemberian akupresure terbukti efektif dalam mengurangi adanya mual muntah. Adapun durasi pemberian akupresure bervariasi mulai dari 15 menit sebelum induksi anastesi sampai 24 jam setelah operasi. Waktu pemberian pun 
bermacam-macam mulai dari pemberian sebelum anastesi maupun setelah operasi. Untuk intervensi dan perbandingan intervensi yang diberikan beragam, mulai membandingkan akupresure P6 dengan sham akupresure, ataupun dibandingkan dengan kontrol yang hanya diberikan obat-obatan.

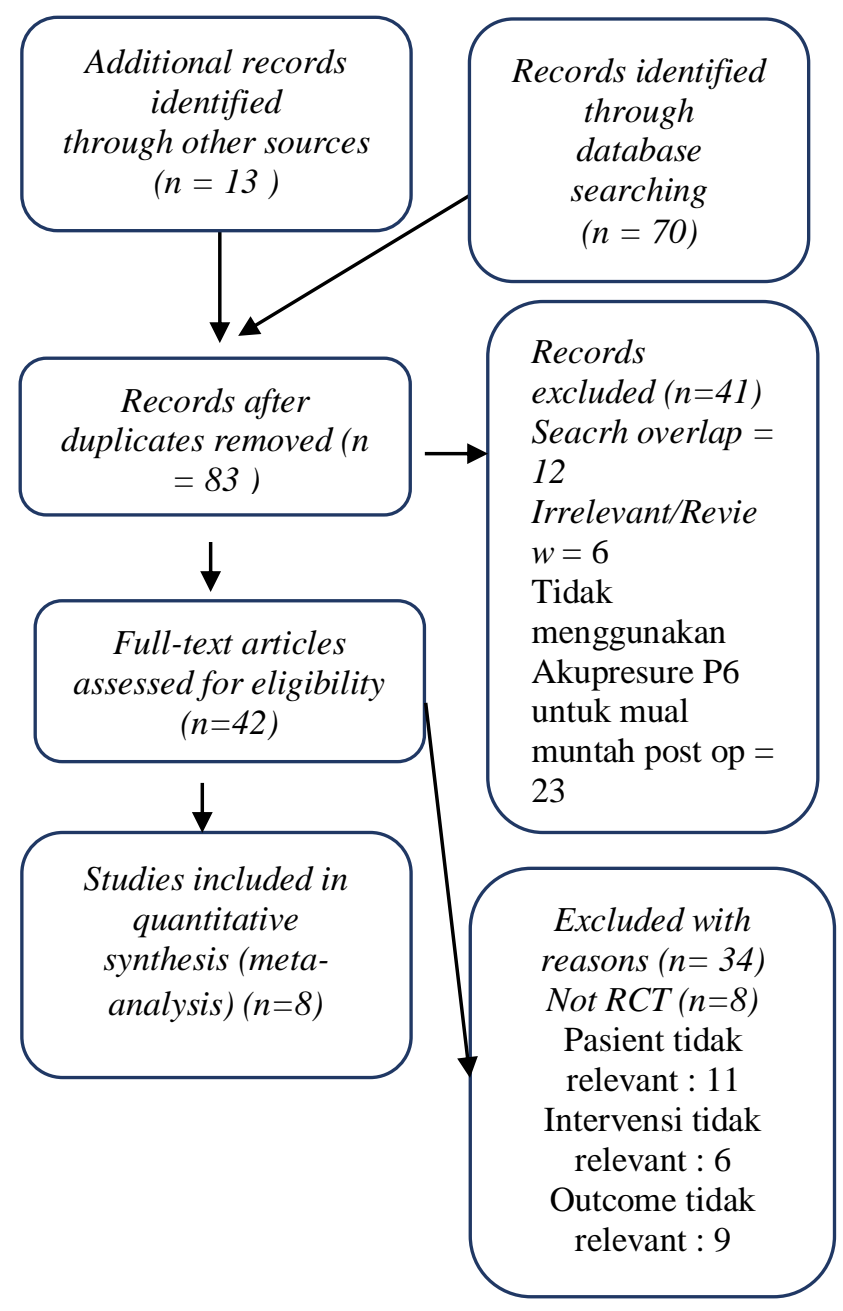

Gambar 1. Prosedur pemilihan literature dengan PRISMA CHART

\section{PEMBAHASAN}

Pemberian akupresure pada titik P6 jika dibandingkan dengan grup kontrol terbukti efektif, hal ini juga sesuai dengan pemberian akupresure dan obat-obatan jika dibandingkan dengan kelompok yang hanya diberikan obatobatan saja. Sebuah penelitian sistematik review menunjukkan bahwa stimulasi akupoint P6 dapat mengurangi resiko terjadinya mual muntah post operasi jika dibandingkan dengan sham akupresure dengan (RR $0.71,95 \%$ CI 0.61 to 0.83 ; RR $0.70,95 \%$ CI 0.59 to 0.83 ; RR $0.69,95 \%$ CI 0.57 to 0.83 ). Pengurangan nausea, vomiting pada terapi akupresure dapat mengurangi biaya, length of stay dan meningkatkan kualitas perawatan. ${ }^{7}$ Jika dilihat dari efek samping yang ditimbulkan dari kedelapan jurnal tersebut tidak terdapat efek samping yang terjadi. Adapun karakteristik review jurnal yang didapatkan dapat dilihat dari tabel 1 di bawah.

Adapun kualitas dari penelitian bervariasi. Dari kedelapan jurnal yang didapatkan disebutkan dengan jelas cara dan pemilihan sampel, kriteria inklusi dan ekslusi penelitian. Akan tetapi dari kedelapan penelitian, hanya 3 yang menyebutkan cara meminimalisir kemungkinan bias secara jelas. Penelitian tersebut termasuk penelitian yang bagus ( good recomendation) karena untuk meminimalisir bias sudah menetapkan sampel melalui random sampling, sebagian besar menggunakan double blind, kriteria inklusi dan ekslusi. Adapun metode perhitungan jumlah sampel yang digunakan tidak dijelaskan secara jelas. Alur penelitian sebagian besar sudah dijelaskan sehingga memudahkan para pembaca untuk memahami maksud dan tujuan penelitian.

Untuk instrument yang digunakan dalam kedelapan penelitian tersebut sudah dijelaskan dengan jelas dan menggunakan beberapa instrumen yang memang sudah baku seperti visual analogue scale, instrument nausea, vomiting and retching (INVR) dan MANE. Statistik yang digunakan sudah sesuai dengan tujuan dan design penelitian. Akupresure P6 merupakan modalitas yang bermanfaat untuk mengurangi mual muntah. Akan tetapi mekanisme dalam mengurangi mual muntah dan waktu dan durasi pemberian akupresure yang efektif untuk mengurangi mual muntah belum jelas.

Sistematik review yang dilakukan oleh Schultz menunjukkan bahwa kombinasi stimulasi akupresure P6 dengan pemberian obat-obatan, jika dibandingkan dengan sham akupresure, sham akupresure tidak memiliki pengaruh yang signifikan dalam mengurangi mual muntah akibat operasi. Schultz membandingkan dengan menggunakan obat droperidol. $^{8} \quad$ Sedangkan pasien yang mendapatkan terapi akupresure dan ondansetron memiliki kualitas recovery lebih 
baik jika hanya dibandingkan dengan penggunaan ondansteron tunggal. ${ }^{9}$

Akupresure merupakan suatu seni pengobatan dengan menggunakan jari untuk menekan titik titik tertentu di tubuh untuk menstimulasi kemampuan tubuh mengobati diri sendiri. Mual muntah terjadi akibat adanya aliran qi yang tidak berada pada alirannya sehingga menyebabkan ketidakseimbangan energi di lambung dan limpa. Tindakan yang dilakukan adalah dengan memanipulasi titiktitik yang berada di sepanjang meridian yang mengenai lambung dan limpa, sehingga energi yang tidak harmonis tersebut kembali ke dalam kondisi seimbang. Energi yang berada dalam kondisi seimbang akan dapat menjalankan fungsinya dalam meberikan nutrisi ke jaringan, mengaktivasi fungsi organ-organ dan keseimbangan fungsi tubuh. ${ }^{10}$

Efek yang dihasilkan oleh manipulasi pada titik adalah memperbaiki kondisi energi yang tidak seimbang tersumbat atau kurang di sepanjang meridian dan organ yang dilewatinya. ${ }^{11}$ Manipulasi pada titik P6 juga dapat bertujuan untuk menenangkan emosi/fikiran dan menghilangkan stress. ${ }^{12}$ Fikiran dan emosi yang baik dapat menimbulkan kondisi rileks pada pasien, sehingga dapat membantu untuk mencegah atau mengurangi mual muntah. Stimulasi yang diberikan pada titik-titik penekanan akupresure memiliki efek terapeutik karena konduksi dari sinyal elektromagnetik yang mampu mendorong aliran zat -zat bikomia pencegah nyeri seperti endorpin dan sel-sel sistem imun ke tempat khusus di tubuh yang mengalami cedera atau rusak karena penyakit dan mengaktivasi sistem opioid sehingga dapat mengurangi nyeri dan muntah. ${ }^{6,10}$

Selain itu, manipulasi pada titik P6 dapat merangsang pengeluaran beberapa neurotransmiter diantaranya beta endorphin yang mempunyai peranan sebagai anti emetik endogen melalui pengaruhnya dalam menurunkan rangsangan pada chemoreseptor triger zone dan pusat muntah. ${ }^{13}$ Selain itu mekanisme akupresure dalam mencegah terjadinya mual muntah dengan menstimulasi pengeluaran endorpin dan serotonin. ${ }^{14}$

Sebuah meta analisis dalam Cochrane Systematic Review yang melibatkan 40 penelitian dengan totoal 4858 partisipan (seluruh pasien bedah tanpa batasan umur) melaporkan bahwa terdapat pengaruh positif dari stimulasi akupoint P6 pada mual (RR $0.71,95 \%$ CI 0.61 to 0.83 ); muntah (RR 0.70, 95\% CI 0.59 to 0.83 ); ; dan kebutuhan akan antiemetik (RR $0.69,95 \%$ CI 0.57 to 0.83 ).$^{15}$ Sebuah penelitian sistematik review yang melibatkan 26 literature menunjukkan hasil bahwa stimulasi akupuntur titik P6 mengurangi insiden mual, muntah, dan kebutuhan akan obat-obatan antiemetik. ${ }^{7}$ Seperti penelitian randomized control trial yang menunjukkan hasil bahwa akupresure dapat mengurangi mual muntah sebaik kelompok kontrol yang diberikan ondansetron, dimana dapat mengurangi insidens mual (19\%) dibandingkan dengan ondansetron $(40 \%)$ dan plasebo $(79 \%) .^{3}$

\section{KESIMPULAN DAN SARAN}

Pasien yang menjalani operasi memiliki resiko cukup tinggi untuk terjadi mual muntah. Pemberian akupresure dapat mengurangi terjadinya mual muntah pada pasien. Tidak ada efek samping yang didapatkan dari review kedelapan literature tersebut. Stimulasi akupresure P6 cocok digunakan sebagai terapi komplementer disamping obat-obatan antiemetk untuk mencegah mual muntah akibat operasi. Untuk penelitian lebih lanjut sebaiknya melakukan penelitian untuk mengetahui durasi pemberian akupresure P6 sehingga dapat memberikan efek mengurangi mual-muntah yang signifikan. 
Tabel 1. Hasil literature review

\begin{tabular}{|c|c|c|c|c|c|c|}
\hline No & $\begin{array}{c}\text { Nama } \\
\text { Penulis/Tahun }\end{array}$ & $\begin{array}{c}\text { Design } \\
\text { penelitian }\end{array}$ & Sampel & Intervensi & $\begin{array}{c}\text { Waktu } \\
\text { pemberian }\end{array}$ & Hasil \\
\hline 1 & $\begin{array}{l}\text { Jian-qin Lv, Rui- } \\
\text { zhi Feng and } \\
\text { Ning Li*/ } 2013\end{array}$ & $\begin{array}{l}\text { a single- } \\
\text { center, } \\
\text { prospective, } \\
\text { double- } \\
\text { blind, five- } \\
\text { arm, } \\
\text { parallel- } \\
\text { group, } \\
\text { randomized } \\
\text { controlled } \\
\text { trial }(R C T)\end{array}$ & $\begin{array}{l}300 \text { pasien } \\
\text { yang akan } \\
\text { menjalani } \\
\text { craniotomy }\end{array}$ & $\begin{array}{l}\text { 1) P6 acupuncture } \\
\text { bilaterally selama } 30 \\
\text { menit, distimulasi setiap } \\
10 \text { menit; 2) sham } \\
\text { acupuncture bilaterally } \\
\text { selama } \\
30 \quad \text { menit tanpa } \\
\text { stimulasi; 3) stimulasi } \\
\text { P6 melalui TENS } \\
\text { elektroda secara bilateral } \\
\text { selma } 30 \text { menit dengan } \\
\text { stimulasi de qi. } 4 \text { ) } \\
\text { stimulasi sham P6 } \\
\text { melalui inactive TENS } \\
\text { electrode bilaterally } \\
\text { selama } 30 \text { minutes; dan } \\
\text { 5) terapi umum dengan } \\
\text { obat-obatan }\end{array}$ & 30 menit & $\begin{array}{l}\text { Stimulasi } \\
\text { akupoint P6 } \\
\text { lebih efektif } \\
\text { jika } \\
\text { dibandingkan } \\
\text { dnegan } \\
\text { standard care } \\
\text { dengan hanya } \\
\text { menggunakan } \\
\text { obat-obatan } \\
\text { pada apsien } \\
\text { craniotomi. }\end{array}$ \\
\hline 2 & $\begin{array}{ll}\text { Min } & \text { Seok } \\
\text { Koo/2013 } & \end{array}$ & $\begin{array}{l}\text { Randomized } \\
\text { controlled } \\
\text { trial (RCT). }\end{array}$ & $\begin{array}{l}184 \text { pasien } \\
\text { yang } \\
\text { menjalani } \\
\text { operasi tiroid }\end{array}$ & $\begin{array}{l}\text { Masing-masing grup : } \\
\text { inactive P6 acupoints, } \\
\text { capsaicum plester, k-D2 } \\
\text { grup, dan sham gorup } \\
\text { dengan capsaicum } \\
\text { plester }\end{array}$ & $\begin{array}{l}\text { Sebelum } \\
\text { anastesi } \\
\text { dan } \\
\text { dilepaskan } \\
8 \text { jam } \\
\text { setelah } \\
\text { operasi }\end{array}$ & $\begin{array}{l}\text { Akupresure } \\
\text { P6 dan KD2 } \\
\text { memiliki } \\
\text { pengaruh } \\
\text { yang } \\
\text { signifikan } \\
\text { dalam } \\
\text { mengurangi } \\
\text { mual muntah } \\
\text { post operasi } \\
\text { tiroid. }\end{array}$ \\
\hline 3 & $\begin{array}{l}\text { Mohsen Adib- } \\
\text { Hajbaghery/2013 }\end{array}$ & $\begin{array}{l}\text { A single- } \\
\text { blind, } \\
\text { randomized } \\
\text { controlled } \\
\text { clinical trial }\end{array}$ & $\begin{array}{l}88 \text { pasien } \\
\text { apendiktomi }\end{array}$ & $\begin{array}{l}\text { Dibagi menjadi } 2 \text { grup : } \\
\text { Grup intervensi } \\
\text { dipasangkan akupresure } \\
\text { dititik P6, sedangkan } \\
\text { grup kontrol dipasang di } \\
\text { lengan tanpa } \\
\text { memperhatikan titik p6. }\end{array}$ & $\begin{array}{l}\text { Dipasang } \\
\text { setelah } \\
\text { operasi } \\
\text { sampai } 7 \\
\text { jam setelah } \\
\text { operasi }\end{array}$ & $\begin{array}{l}\text { Akupresure } \\
\text { dapat } \\
\text { megurangi } \\
\text { insiden mual } \\
\text { muntah. }\end{array}$ \\
\hline 4 & $\begin{array}{l}\text { Ashraf } \\
\text { Direkvand- } \\
\text { Moghadam1, } \\
\text { AfraKhosravi2 } \\
\text { Also/2013 }\end{array}$ & $\begin{array}{l}\text { randomized } \\
\text { clinical trial } \\
\text { study }\end{array}$ & $\begin{array}{lr}102 \quad \text { pasien } \\
\text { sectio secsaria } \\
\text { dibagi } \\
\text { menjadi } \quad 3 \\
\text { grup : masing- } \\
\text { masing } \quad 34 \\
\text { orang. }\end{array}$ & $\begin{array}{l}\text { Grup kontrol tidak } \\
\text { diberikan intervensi } \\
\text { apapun, grup } 2 \text { diberikan } \\
10 \text { mg Metoclopramide } \\
\text { intravenousl, grup } 3 \\
\text { diberikan akupresure p6 } \\
\text { selama } 15 \text { menit } \\
\text { sebelum anastesi. }\end{array}$ & $\begin{array}{l}15 \text { menit } \\
\text { sebelum } \\
\text { operasi }\end{array}$ & $\begin{array}{l}\text { Akupresure } \\
\text { terbukti dapat } \\
\text { mengurangi } \\
\text { adanya mual } \\
\text { muntah }\end{array}$ \\
\hline 5 & $\begin{array}{lll}\text { Cooke, } & \text { M } & \text { et } \\
\text { al/2014 } & & \end{array}$ & $\begin{array}{l}\text { two-group, } \\
\text { parallel, } \\
\text { superiority, } \\
\text { randomised } \\
\text { controlled } \\
\text { trial }\end{array}$ & $\begin{array}{l}712 \text { pasien } \\
\text { cardiac } \\
\text { surgery }\end{array}$ & $\begin{array}{lr}\text { Diberikan } & \text { intervensi } \\
\text { obat-obatan } & \text { dan grup } \\
\text { lainnya } & \text { diberikan } \\
\text { acupresure P6 selama } 36 \\
\text { jam setelah surgery. }\end{array}$ & $\begin{array}{l}36 \text { jam post } \\
\text { operasi }\end{array}$ & $\begin{array}{l}\text { Akupresure } \\
\text { terbukti dapat } \\
\text { mengurangi } \\
\text { adanya mual } \\
\text { muntah }\end{array}$ \\
\hline 6 & $\begin{array}{l}\text { Paul F. White/ } \\
2012\end{array}$ & $\begin{array}{l}\text { two-group, } \\
\text { parallel, } \\
\text { superiority, }\end{array}$ & $\begin{array}{l}100 \text { pasien } \\
\text { dengan } \\
\text { pysical status }\end{array}$ & $\begin{array}{l}\text { Grup kontrol diberikan } \\
\text { sham akupresure } \\
\text { sedangkan grup }\end{array}$ & $\begin{array}{l}30-60 \\
\text { menit } \\
\text { sebelum }\end{array}$ & $\begin{array}{l}\text { Akupresure } \\
\text { terbukti dapat } \\
\text { mengurangi }\end{array}$ \\
\hline
\end{tabular}




\begin{tabular}{|c|c|c|c|c|c|c|}
\hline No & $\begin{array}{c}\text { Nama } \\
\text { Penulis/Tahun }\end{array}$ & $\begin{array}{c}\text { Design } \\
\text { penelitian }\end{array}$ & Sampel & Intervensi & $\begin{array}{c}\text { Waktu } \\
\text { pemberian }\end{array}$ & Hasil \\
\hline & & $\begin{array}{l}\text { randomised } \\
\text { controlled } \\
\text { trial }\end{array}$ & 1 dan 2 & $\begin{array}{l}\text { intervensi diberikan } \\
\text { Pressure Right device } \\
\text { placed bilaterally at the } \\
\text { P6 selama } \\
\text { s0-60 menit } \\
\text { sebelum anastesi. } \\
\text { Seluruh } \\
\text { diberikan oblompok } \\
\text { antiemetik. }\end{array}$ & anastesi. & $\begin{array}{l}\text { mual muntah } \\
12,24,36 \text { dan } \\
72 \text { jam stelah } \\
\text { operasi. }\end{array}$ \\
\hline 7 & $\begin{array}{l}\text { Boehler et } \\
\text { al/2002 }\end{array}$ & $\begin{array}{l}\text { a double- } \\
\text { blinded, } \\
\text { randomized, } \\
\text { placebo- } \\
\text { controlled } \\
\text { study }\end{array}$ & $\begin{array}{l}80 \text { pasien } \\
\text { Gynecological } \\
\text { Laparoscopic } \\
\text { Surgery }\end{array}$ & $\begin{array}{l}\text { Kelompok } \begin{array}{l}\text { intervensi } \\
\text { diberikan akupresure }\end{array} \\
\text { pada titik P6 dan KD2 } \\
\text { dan kelompok kontrol } \\
\text { tidak diberikan apapun }\end{array}$ & $\begin{array}{l}\text { Intervensi } \\
\text { dilakukan } \\
30 \text { menit } \\
\text { sebelum } \\
\text { induksi } \\
\text { anastesi } \\
\text { dan } \\
\text { dibiarkan } \\
\text { selama 24 } \\
\text { jam setelah } \\
\text { operasi. }\end{array}$ & $\begin{array}{l}\text { Akupresure } \\
\text { terbukti } \\
\text { mengurangi } \\
\text { mual muntah } \\
\text { akibat } \\
\text { operasi. }\end{array}$ \\
\hline 8 & $\begin{array}{l}\text { Arnberger } \\
\mathrm{M} / 2007\end{array}$ & $\begin{array}{l}\text { a double- } \\
\text { blinded, } \\
\text { randomized, } \\
\text { placebo- } \\
\text { controlled } \\
\text { study }\end{array}$ & $\begin{array}{l}72 \text { pasien } \\
\text { cardiac } \\
\text { surgery }\end{array}$ & $\begin{array}{l}\text { Kelompok intervensi } \\
\text { diberikan akupresure P6 } \\
\text { sebelum induksi anastesi } \\
\text { dan dibiarkan selama } 12 \\
\text { jam setelah operasi. } \\
\text { Kelompok kontrol tidak } \\
\text { diberikan perlakuan } \\
\text { apapun. Kedua } \\
\text { kelompok diberikan obat } \\
\text { eantiemetik. }\end{array}$ & $\begin{array}{l}\text { Akupresure } \\
\text { diberikan } \\
\text { sebelum } \\
\text { anastesi } \\
\text { dan } 12 \text { jam } \\
\text { setelah } \\
\text { anastesi } \\
\text { dilepaskan. }\end{array}$ & $\begin{array}{l}\text { Akupresure } \\
\text { terbukti } \\
\text { mengurangi } \\
\text { mual muntah } \\
\text { akibat } \\
\text { operasi. }\end{array}$ \\
\hline
\end{tabular}

\section{DAFTAR PUSTAKA}

1. Watcha MF WP. Postoperative nausea and vomiting: its etiology, treatment and prevention. Anesthesiology [Internet]. 1992;77(1):162-184. Available from:https://doi.org/10.1097/00000542199207000-00023

2. Sadhasivam S, Saxena A, Kathirvel S, Kannan TR, Trikha A M V. The safety and efficacy of prophylactic ondansetron in patients undergoing modified radical mastectomy. Anesth Analg [Internet]. 1999;89(6):1340-1345. Available from:https://doi.org/10.1097/00000539199912000-00002.

3. Gan TJ, Meyer T, Apfel CC, Chung F, Davis PJ, Eubanks S, Kovac A, Philip BK, Sessler DI, Temo J, Tramer MR WM. Consensus guidelines for managing postoperative nausea and vomiting. Anesth Analg [Internet]. 2003;97(1):62-71. Available from: http://doi.org/10.1213/01.ane.0000068580. 00245.95 .
4. Sanchez-Ledesma MJ, Lopez-Olaondo L, Pueyo FJ, Carrascosa F O. A comparison of three antiemetic combinations for the prevention of postoperative nausea and vomiting. Anesth Analg [Internet]. 2002;95(6):1590-1595. Available from:https://doi.org/10.1097/00000539200212000-00022

5. Habib AS, El-Moalem HE GT. The efficacy of the 5-HT3 receptor antagonists combined with droperidol for PONV prophylaxis is similar to their combination with dexamethasoneA meta-analysis of randomized controlled trials. Can J Anaesth [Internet]. 2004;51(4):311-319. Available from: https://doi.org/10.1007/BF03018234

6. Jian-qin Lv RF and NL. P6 acupoint stimulation for prevention of postoperative nausea and vomiting in patients undergoing craniotomy: study protocol for a randomized controlled trial. Trials. [Internet]. 2013;14(153) 10.1186/17456215-14-153 
7. Lee, A and Fan, LTY. Stimulation of the wrist acupuncture point P6 for preventing postoperative nausea and vomiting. Cochrane Database Syst Rev. [Internet]. 2009; 15(2):1-64. Available from: https://doi.org/ 10.1002/14651858.CD003281.pub3.

8. Schultz A, Andrews AL, Goran S, Mathew T. Comparison of acupressure bands and droperidol for reducing post-operative nausea and vomiting in gynecologic surgery patients. Appl Nurs Res [Internet]. 2003;16(4):256-65. Available from: https://doi.org/10.1016/s08971897(03)0005 7-0.

9. White PF, Issioui $\mathrm{T}, \mathrm{Hu} \mathrm{J}$, Jones $\mathrm{SB}$, Coleman JE WJ. Comparative efficacy of acustimulation (ReliefBand) versus ondansetron (Zofran) in combination with droperidol for preventing nausea and vomiting. Anesthesiology [Internet]. 2002;97(5):1075-1081. Available from: https://doi.org/10.1097/0000054220021100 0-00008

10. Lindquist R, Snyder M, Tracy MF. Complementary \& Alternative Therapies in Nursing. 7th ed. New York: Springer Publishing Company; 2014.

11. Dibble SL, Luce J, Cooper BA, Israel J, Cohen M, Nussey B\&, et al. Acupresure for chemotherapy- induced nausea and vomiting: A randomized clinical tria. Oncol Nurs Forum [Internet]. 2007;34(4):813820. Available from: https://doi.org/10.1188/07.ONF.xxx-xxx

12. Yapeptri. (2008). Pedoman Praktis Akupresur. Jakarta : Departemen Kesehatan RI. Direktorat Jendral Pembinaan Kesehatan Masyarakat. Direktorat Bina Peran Serta Masyarakat. Tidak dipublikasikan.

13. Samad K, Afshan G, Kamal R. Effect of acupressure on postoperative nausea and vomiting in laparoscopic cholecystectomy. J Pak Med Assoc. 2003;53(2):68-72.

14. Turgut S, Ozalp G, Dikmen S, Savli S, Tuncel G, Kadiogullari N. Acupressure for postoperative nausea and vomiting in gynaecological patients receiving patientcontrolled analgesia. Eur $\mathrm{J}$ Anaesthesiol [Internet]. 2007;24(1):87-91. Available from:https://doi.org/10.1017/S0265021506 001190

15. Lee A, Fan LT. Stimulation of the wrist acupuncture point P6 for preventing postoperative nausea and vomiting. Cochrane Database Syst Rev [Internet]. 2011; Available from: https://doi.org/10.1002/14651858.CD00328 1.pub3. 